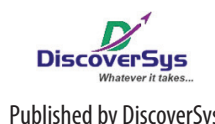

Published by DiscoverSys

\section{Early marriage practices and the health impacts on female adolescent health in Central Lombok: a qualitative study}

\author{
Baiq Rizka Herliana, ${ }^{*}{ }^{*}$ Ni Wayan Arya Utami, ${ }^{2}$ Desak Putu Yuli Kurniati ${ }^{2}$
}

\section{ABSTRACT}

Background and purpose: Early marriage through merariq or eloping tradition is a common practice in West Nusa Tenggara particularly in Central Lombok. Early marriage leads to several negative consequences on the reproductive health of female adolescents. This study aims to explore early marriage practices and its impacts on the reproductive health of female adolescents in Central Lombok.

Methods: A qualitative study with a case study approach was conducted, and seven early married female adolescents purposively selected as the study participants. Interviews were also conducted with two family members of the female adolescents, one community leader, and a midwife who worked as an adolescent health coordinator at a public health centre. Data were analyzed using a thematic approach to map the reasons for early marriage and its impacts on the reproductive health of female adolescents.

Results: Our in-depth interviews revealed that several reasons associated to early marriage practices were: lacking in knowledge regarding the effects of early marriages, perceived benefits of early marriages including perception on maturity and logical thinking, and social sanctions from the society because it considered a disgrace when the eloped girl returned home. Several negative consequences of early marriages emerged from this study were complicated pregnancy/delivery, low birth weight, and undernourished children. Our informants concerned about the psychological effects of early marriages which include fear, regret, and depression. Eloped female adolescents lose their agency for decision making including the right for further education.

Conclusions: Early marriage practices bring negative health consequences to female adolescents. An active collaboration across health sector and community leaders is required to provide sufficient information regarding the harmful effects of early marriages. Also, a more effective communication strategy using a family-based approach is required to appropriately target female adolescents with health information associated with the impacts of early marriage.

Keywords: early marriage, health impacts, adolescent health, Central Lombok

Cite This Article: Herliana, B.R., Utami, N.W.A., Kurniati, D.P.Y. 2018. Early marriage practices and the health impacts on female adolescent health in Central Lombok: a qualitative study. Public Health and Preventive Medicine Archive 6(1):61-67. D0I:10.15562/phpma.v6i1.11

${ }^{1}$ Yarsi Health Institute, Mataram, ${ }^{2}$ Department of Public Health and Preventive Medicine, Faculty of Medicine, Udayana University
${ }^{*}$ Correspondence to: Baiq Rizka Herliana, Yarsi Health Institute, Mataram,

baiqrizkaherliana@gmail.com

\section{INTRODUCTION}

Early marriages in Indonesia remains high. Indonesia was ranked $37^{\text {th }}$ across the globe in 2013 in terms the proportion of early marriages and was ranked $2^{\text {nd }}$ across ASEAN countries after Cambodia. ${ }^{1}$ The 2013 Indonesia Basic Health Research (Riskesdas) showed that the proportion of early marriages among teenagers was $2.6 \%$ among aged $<15$ yearsold and $23.9 \%$ for aged $15-19$ years-old. ${ }^{2}$

West Nusa Tenggara is a province in Indonesia with high maternal mortality ratio (MMR) which was 92 per 100,000 live births. ${ }^{3}$ The high MMR in West Nusa Tenggara is contributed by the high prevalence of teenage pregnancies due to early marriages. ${ }^{3}$ The National Demographic and Family Planning Board (BKKBN) reported that Central Lombok District had the highest prevalence of early marriages (age $<20$ years old) in $2016(4.39 \%)$, followed by Dompu District (3.97\%), North Lombok District (3.67\%), East Lombok District (3.58\%), and Mataram City (1.52\%). ${ }^{4}$
As a response to the growing prevalence of early marriages, the government released the Governor Regulation No. 150/113/Kum which recommends the minimum age of marriage of 21 years-old for both men and women. ${ }^{5}$ Studies on early marriages and its impacts have been conducted in West Nusa Tenggara. These studies mainly explored the reasons for early marriages from female adolescents' perspective. However, the existing studies rarely dealed with the perception of female adolescents on the health effects of such marriages, primarily for sexual and reproductive health. Our study aims to explore early marriage practices and its impacts on the reproductive health of female adolescents in Central Lombok.

\section{METHODS}

A qualitative study using a case study approach was conducted and seven female adolescents who married at a young age were interviewed. They were 
purposively selected based on predefined criteria: ${ }^{6}$ ever pregnant or had given birth, able to communicate clearly, willing to participate in the study, and residing at Batunyala Village.

In-depth interviews were conducted by the researcher using an interview guide ${ }^{7}$ covering several topics, and all interviews were recorded. Transcripts of the interviews combined with the field notes were compiled into a single document to guide our analysis.

Data were analyzed using a thematic approach. Firstly, certain keywords or phrases which emerged from the transcripts were identified. This coding process allowed some data comparison between informants. Secondly, we categorized and collated several codes into categories, and finally collating some categories into core themes. Data were presented using the narrative approach by laying out core themes emerged from our case studies. The inductive and deductive approaches were employed when discussing our themes to generate conclusions. Triangulation method was used to increase the rigor of the study by interviewing two parents of our key informants, one community leader, and a midwife who is also the head of adolescent health program at a public health center (PHC). Our study protocol has been approved by the Human Research Ethics Committee Faculty of Medicine Mataram University on April 18 $8^{\text {th }}, 2017$.

\section{RESULTS AND DISCUSSION}

Our findings are presented in several key themes emerging from the analysis which include the reasons for early marriages and the impacts of early marriages on the reproductive health of female adolescents. Reasons for early marriage emerged from our study included lack of knowledge about the negative consequences of early marriages, positive attitudes toward early marriage practices, and social sanctions. The physical health effects of early marriage practices are low birth weight, malnutrition, and complicated pregnancy/delivery, while the psychological health effects include fear, regret, and depression. The social effects of early marriages were also identified, which included limited access to education as well as reduced control over their body.

\section{Lack of knowledge on the health effects of early marriages}

Our interviews revealed that the key informants were generally aware of the ideal age for marriage (around 20 years-old). However, they have little understanding of the negative consequences of early marriages to their health. This can be seen from the following quotes:
".... [ideal age for marriage] for women is 20 years-old and 25 years-old for men... I don't know the negative consequences [of early marriage] to my health, I never heard of it, maybe it was mentioned in my science subject at school, but it was a long time ago, I forgot it already..." (NP, 21 years-old, a housewife)

".... [ideal age for marriage] is maybe above 17 years-old... I don't know the negative consequences of early marriage to my health...." (SD, 16 years old, a housewife)

A consistent finding was found in the interview with the village secretary. It was claimed that the lack of knowledge on sexual and reproductive health (SRH) contributes to the high prevalence of early marriages among adolescents in his jurisdiction. He further said that there were insufficient SRH education programs under his jurisdiction.

"...I think, from my observation, they [female adolescents] have limited knowledge on SRH because I see very few SRH education programs from the religion affair office (or Kantor Urusan Agama/KUA) or local governments, they only talk about drugs, they rarely discuss sexual and reproductive health...." (HS, 49 years-old, the village secretary).

Married adolescents tend to have limited knowledge about health consequences arising from early marriages for example pregnancy, sexual health, and reproductive function. A study in Banyuwangi District found that only $5 \%$ of female adolescents were aware of the consequences of early marriages to their health. ${ }^{8}$ Similarly, another study in 2007 found a significant association between early marriage practices, SRH knowledge, and understanding of health consequences of early marriages. ${ }^{9}$

Knowledge is a critical domain of behavior. ${ }^{10}$ The lack of SRH knowledge may lead to negative SRH behaviors. A study in Tana Toraja District found that the lack of SRH knowledge among female adolescents was the main factor associated with early marriage practices. ${ }^{11}$ These findings suggest that local governments in collaboration with community leaders should be proactive in promoting the Marriage Law to the wider population and should provide ongoing support to families or communities to delay marriage age. Furthermore, they should encourage the village youth organization to provide ongoing SRH education programs. 


\section{Positive perspectives regarding early marriages}

The lack of SRH knowledge and understanding on the negative consequences of early marriages to SRH will influence the perceptions of female adolescents about early marriages. Our study found that the majority of participants have positive attitudes towards early marriages. They perceived that the benefits of early marriages outweigh the risks. The following quotes illustrate the positive attitudes of participants.

".... know that I married early, and I agree to do it [laughing]... [There are] benefits from early marriage, live together, having children, happy together, and the risk maybe we will argue, that's it... I think it gives more benefits hehe...." (NP, 21 years-old, a housewife).

"...It is good, more mature; you can determine what is good or bad for yourself... I feel free I mean less restriction..." (AI, 18 years-old, a housewife).

Some participants expressed their negative perceptions about early marriages and experienced some degree of domestic violence. A teenage wife aged 16 years-old stated that she was distressed and often physically abused by her husband as can be seen in the following quote:

“...I disagree with early marriage, I experienced it and you know it was like this, I can't cope much longer, there are no benefits from it, I regret it now (crying)...." (SD, 16 years old, a housewife).

This study found that female adolescents have a strong belief on the positive outcomes from the early marriages. They believed that early marriages associated with more benefits than risks, for example, the maturity and ability to make decisions. These beliefs lead to positive attitudes toward early marriage practices. A study in West Java found that the perception of female adolescents in rural areas on early marriage practices was associated with personal experiences and interactions within the wider society. The lack of knowledge about the meaning and function of families contributed to a narrow comprehension of the ideal family life and decision around early marriages. ${ }^{12}$

The parents also have positive attitudes toward early marriages due to social and cultural reasons. Within the local contexts, the most important thing to do as female adolescents is to get married and have children. The negative health consequences are often overlooked. Moreover, the parents considered it was a disgrace when their daughter was divorced or returned home by her husband.

"....It is normal if they [teenage girls] will experience some difficulty during labor because they are still young, but you know we should pray to God and wish them the health and they can deliver the baby safely, insyaAllah I said. We all should pray, you know the neighbor or their aunts will also say it will be difficult to deliver the baby because they married early, but we should not think that way, we all should pray so they can give birth safely...." (NDK, 47 years-old, trader).

In contrast to our research, a study in Bandar Lampung City in 2013 found that the parents tend to have negative attitudes toward early marriages. They perceived that early marriages would take away the opportunity of female adolescents for better education. ${ }^{13}$ Socio-cultural factors may contribute to this difference. In the context of Central Lombok, it would be a disgrace if an eloped female adolescent returned home, leading to the acceptance of early marriage practices.

\section{Social consequences from the society}

A non-conforming behavior within the study location will be materially and socially punished. In our study location, almost all eloped girls were reluctant to go back to their house even though the marriage is unwanted. They were more afraid of social punishments from the communities as well as their peers. This can be seen in the following quotes:

"...I want to go back home, but I feel embarrassed, well he already brought me here at my husband house, you know I also feel ashamed especially with my peers, people will talk about me, they will say 'why is she back? She married already'...." (EL, 23 years-old, a housewife).

"....My families were mad at me because I married too young, but it had already happened. I feel embarrassed if I go back, he already brought me here. The community members will mock me; they will say 'pengantin tidak jadi' [or a fail bride]...." (YN, 18 yearsold, a housewife).

Similarly, the parents expressed this social punishment regarding being mocked by the rest of the community members. It is a disgrace if the eloped girl goes back to her parent's house. 
"... You know, it is very common... the community will mock her, and she might feel ashamed... We concern about her mental health condition... It will be more complicated if hmm what if she went crazy, you know we concern about it..." (JW, 34 years-old, a housewife).

Early marriage in Lombok Island is influenced by the merariq [or eloping] tradition. This tradition is not written, however, is widely practiced by the society. A girl who has been kidnapped or eloped is forbidden to go back to her parent's house because it considers being a disgrace to the whole families. ${ }^{14}$ Regardless whether the marriage is desirable or unwanted, due to these social punishments the eloped girls will accept the marriage. They are afraid of these social punishments especially from their peers and their neighborhoods. This finding is consistent with the planned behavior theory that a strong control belief of teenage girls in our study location will manifest in their behaviors. The strong belief on social punishments and the lack of positive social support from the surrounding environments lead to the practice of early marriage. ${ }^{15}$

\section{Perception on the health impacts of early marriages to female adolescents}

The BKKBN stated that the impacts of early marriages mainly affected female adolescents including complicated pregnancy; reduced access to education; domestic violence; and poverty. ${ }^{16}$ The impacts of early marriage practices were ranging from physical, psychological, and social issues. It affects the sexual and reproductive health of female adolescents. The small size of the pelvic cavity of female adolescents could lead to complicated delivery/labor. Pregnancy among young women is associated with high complication and mortality rates. Female adolescents aged 10 to 14 years old are five times more likely to die due to complications associated with pregnancy when compared to women aged 20-24 years-old. Moreover, female adolescents aged between 15-19 years-old are two times more likely to die due to similar causes when compared to female aged 20-24 years-old. ${ }^{17}$

Most female adolescents in our study are not aware of the health risks arising from early marriages. Some participants said that they must undergo a cesarean section because their pelvic cavity was narrow for normal delivery. Other informants said that they were anemic during pregnancy, while some also complained that their weight mildly increased during the pregnancy. By looking at the $\mathrm{MCH}$ book of the participants, it was found that some participants were anemic (hemoglobin level of <11gr\%) and malnourished (upper arm circumference of $<23.5 \mathrm{~cm}$ ). This can be seen from the following quote:

“....You know, at night there were only $3 \mathrm{~cm}$ dilation, and it remained constant until $11.30 \mathrm{pm}$, the doctor told us to do the operation in the morning, they also told me because my pelvic cavity was small for normal delivery, well they said my baby was too big..." (NP, 21 years-old, a housewife).

Early marriages affect the sexual and reproductive health of female adolescents. Rapid physical growth commonly occurs within this age including the development of sexual organs and reproductive functions. ${ }^{18}$ Also, early marriages inhibit women to plan their pregnancy. Early marriages, therefore, will affect the health of the children, not only from the complications during pregnancy or delivery but also from insufficient parenting skills especially within the first five years of the children growth and development. One participant, for instance, said that she gave birth to a small baby. Low birth weight, in this case, might be the result of competing for nutrient intakes between the teenage mother and the baby. ${ }^{19}$ A study in 2016 found that teenage pregnancies were associated with higher complications including anemia, hyperemesis, non-exclusive breastfeeding, and low birth weight. ${ }^{20}$ Also, the lack of parenting skills leads to the child growth and development issues including malnutrition. This can be seen in the following quotes:

"....The birth weight of my baby was only 2 kilograms, yeah very small at birth..." (AN, 20 yearsold, a housewife).

".... [My son] is three and a half years old, but his weight remained constant over the last 1.5 years, 10 kilograms, he must be malnourished, but now he is chubby......." (EL, 23 years-old, a housewife).

Early marriage is associated with psychological distress among the couple because they are mentally unprepared for the marriage life. Often, they regret their decision as they might lose their teenage life and education opportunity. Fear, regret, and other psychological distress including the intention to divorce are common among unwanted marriage as reflected in the following quotes:

"....My in law is temperamental, and I am afraid of them, if I speak to my mother they will mad at me, they said that I talked a lot to my mother, even they blamed me if I visited my parent's house (whispering)..." (AN, 20 years-old, a housewife). 
".... There are] many disadvantages of such marriage, I regret it now, I made a wrong decision, but it has happened not much that I can do...." (AN, 20 years-old, a housewife).

One informant who is in the process of divorce stated that she was unable to cope with her abusive husband. For a period duration of the interview, she cried telling her experiences being physically abused by her husband as can be seen in the following quote:

"....I can't take it anymore, since our marriage, I was slapped and physically abused (cried)... He slapped me in the face, one time he also wanted to hang me, he tied a rope around my neck, I was feeling unwell back then, so I could not cook for him, I don't know, before the marriage he was fine..." (SD, 16 years old, a housewife).

An early marriage couple is generally unprepared for the marriage life leading to multiple psychological distresses, regret, and also domestic violence. A study in Bangladesh in 2007 found that early marriage contributes to the high divorce rate, second marriage, lack of educational attainment for teenage girls, and reduced quality of marriage life. ${ }^{21}$ Perceived benefits and risks of early marriage are associated with psychological distress. Lack of understanding on the consequences of early marriages and lack of maturity while making such decision lead to psychological issues among female adolescents. Our informants said that they feel 'tied' and their 'freedom' is taken away as can be seen in the following quote:

"....before my marriage I can easily go out with my friends, but now I can't do it anymore, I am not allowed to hang out with my friends, but you know I used to it now, if my husband says no, I have to follow it......" (YN, 18 years-old, a housewife).

Our study revealed that most female adolescents are unable to accept their marriage fully. Their statements reflect that they regret the negative consequences of such marriage. However, they accept these consequences and try to cope with it. In contrast, some informants who have no traumatic experiences with their marriage fully accept their new role and the marriage life as can be seen in the following quote:

".... It is] normal, I feel just fine, you know people will die eventually, some maybe during giving birth, there are few cases like this, you know if you are young often difficult to give birth, and you must be operated,......." (AI, 18 years-old, a housewife).
Several studies showed that married female adolescents are more vulnerable to depression, anxiety disorder, or suicidal which are associated with the lack of social support, status, power/ agency, and control over their own body/life. . $22,23^{2}$ Also, they often regret their decision because they lose their freedom and they must be responsible for domestic work and take care of the children. ${ }^{24}$

The other social consequences of early marriages are reduced access to sexual and reproductive health rights. After the marriage, female adolescents have limited capacity to express their opinion regarding sexual activities and negotiation, contraceptive methods, having children and other domestic issues. ${ }^{25}$ One informant said that she wants to delay the pregnancy, but her husband wants to have children immediately as can be seen in the following quote:

"....I actually want to delay the pregnancy, but my husband wants to have kids because his cousins already have kids... but I am still very young, and I am afraid that I can't take care of my children..." (SD, 16 years-old, a housewife).

This finding shows the low bargaining position of female adolescents after the marriage, especially about sexual and reproductive health. Another informant said that she was told by her parent to use contraception to prevent the pregnancy.

“....My parent does not want me to be pregnant at an early age, they suggest me to use contraceptive (injected), and therefore it was difficult for me to get pregnant, five years..." (EL, 23 years-old, a housewife).

In our study location, women are socially perceived as 'weak individuals', and they should follow all decisions made on their behalf even though it contradicts their own will. 'Sasak' society is patriarchal, where the status of men is higher than women. Gender discrimination especially related to sexual and reproductive health is a common phenomenon in Sasak society, for example, the eloped tradition which leads to early marriage forces women to accept the marriage. This tradition at least violates two fundamental rights of women: the right to decide their life partner and the right to attain better education. ${ }^{26}$

"...I didn't finish my study, and I regret it now, lack of education, I want to go to school again..." (EL, 23 years-old, a housewife).

The early marriage practices violate the right of children to attain education. ${ }^{27}$ A qualitative study in 
eight locations across Indonesia regarding the early marriage practices including the merariq tradition, found that this marriage could not be registered because of the age. Any children from this marriage could not be registered to issue the birth certificate for the legal purposes. If this couple is separated, by law, this marriage never exists. Consequently, female adolescent more likely will lose the parental right for their children. ${ }^{28}$

An ongoing collaboration between health providers and village officials, family planning officials, and community leaders to establish youth education programs at the village level needs to be improved to provide better access to information related to SRH and family planning. The existing youth organi-zation called Karang Taruna at the village level can be used as the point of departure. The SRH education programs can be built within the existing programs of Karang Taruna. ${ }^{29}$

\section{CONCLUSION}

The main reasons for early marriages among teenage girls are the lack of knowledge about the negative consequences of early marriages, positive attitudes towards early marriages, and social sanctions. The health impacts of early marriages include physical and psychological, as well as social consequences such as reduced access to education and limited control over their reproductive health and rights. Our study suggests the critical role of cultural interventions to promote the attitude shift among female adolescents and their families by understanding the sociocultural contexts of the targeted societies.

\section{ACKNOWLEDGEMENT}

We would like to thank all key informants for participating in our study, as well as all related stakeholders who had supported this study including the Head of Batunyala Village.

\section{REFERENCES}

1. Ministry of Health of Indonesia. Situasi kesehatan reproduksi remaja [Reproductive health situation among adolescents]. The Center of Data and Information, Ministry of Health of Indonesia. Jakarta. 2013.

2. Ministry of Health of Indonesia. Riset Kesehatan Dasar (Riskesdas) 2013 [The 2013 Indonesia Basic Health Research]. Ministry of Health of Indonesia. Jakarta. 2014.

3. West Nusa Tenggara Provincial Health Office. Profil Kesehatan Provinsi NTB tahun 2015 [The 2015 Health Profile of West Nusa Tenggara Province]. West Nusa Tenggara Provincial Health Office. Mataram. 2016.
4. National Demographic and Family Planning Board. Laporan Tahunan [Annual Report]. West Nusa Tenggara. 2015.

5. TEMPO.CO. NTB, provinsi pertama atur pendewasaan usia perkawinan [West Nusa Tenggara, the first province which regulates the legal age for marriage]. 22 June 2015. Available at: https://nasional.tempo.co/ $\mathrm{read} / 677284 / \mathrm{ntb}$-provinsi-pertama-atur-pendewasaanusia-perkawinan.

6. Sugiyono. Metode penelitian kuantitatif, kualitatif dan R\&D [Qualitative and quantitative research methods and R\&D]. Bandung : Alfabeta. 2014

7. Herdiansyah H. Metode penelitian kualitatif [Qualitative research methods]. Jakarta: Salemba Humanika, 2011.

8. Andrian, Kuntoro. Abortus spontan pada pernikahan usia dini [Misscariage in early marriage]. Jurnal Biometrika dan Kependudukan. 2013;2(1): 1-9.

9. Hidayati W. Analisis beberapa faktor yang berhubungan dengan perkawinan wanita usia muda (tesis) [An analysis of factors associated with early marriage among young female (thesis)). Universitas Padjajaran, 2007.

10. Sunaryo. Psikologi untuk keperawatan [Psychology for nursing students]. Jakarta: EGC, 2004.

11. Landung J, Thaha R, Abdullah AZ. Kebiasaan pernikahan usia dini pada masyarakat Kecamatan Sanggalangi Kabupaten Tana Toraja [Early marriage tradition among societies in Sanggalangi Subdistrict, Tana Toraja District]. Jurnal Media Kesehatan Masyarakat Indonesia. 2009; 5(4): 89-94.

12. Homzah S. dan Sulaeman M. Motif (faktor pendorong) dan persepsi kawin usia muda pada remaja pedesaan di Jawa Barat [Enforcing factors and the perception of adolescents living in rural villages on early marriage in West Java]. 2007. Available at: http://pustaka.unpad.ac.id/ wp-content/uploads/2014/03/Motif-Faktor-PendorongDan-Persepsi-Kawin-Usia-Muda.pdf

13. Rosilayati, Pitoewas B, Nurmalisa Y. Persepsi orang tua terhadap pernikahan dini di Kelurahan Garuntang [The perception of parents on early marriage in Garuntang Village]. 2014. Available at: http://download.portal garuda.org/article . php? article $=289021 \& \mathrm{val}=7237 \&$ title $=$ PERSEPSI $\% 20$ O R A N G \% 20 T U A \% 20 T E R H A D A P \% 20 PERNIKAHAN\%20DINI\%20DI\%20KELURAHAN\%20 GARUNTANG

14. Tahir M. Tradisi 'merariq' (kawin lari) dalam Masyarakat Sasak (sebuah telaah konsepsi, responsi dan implikasi) [Merariq tradition (eloping) in Sasak Society: an analysis of concepts, responses, and its implications]. In: Harga diri dan ekspresi budaya lokal suku-bangsa di Indonesia [Selfesteem and expression of local culture of ethnic groups in Indonesia]. Yogjakarta: Laboratorium Religi dan Budaya Lokal, Fakultas Ushuluddin, pp. 35-76. 2012

15. Ajzen I. The Theory of Planned Behavior. Organizational Behavior and Human Decision Processes. 1991; 50 (2): 179-211.

16. National Demographic and Family Planning Board. Pedoman pengelolaan bina keluarga remaja [Guideline for managing teenage families]. Jakarta, 2012.

17. Amelia R, Mohdari, Azizah A. Pengaruh penyuluhan terhadap pengetahuan remaja tentang pernikahan dini di Kelas VIII di SMP Negeri 4 Banjarmasin [The effects of health education on the level of knowledge on early marriage among year 8 students in Public Junior High School 4 Banjarmasin]. Dinamika Kesehatan. 2017; 8(1).

18. Kumalasari I. Kesehatan reproduksi untuk mahasiswa kebidanan dan keperawatan [Reproductive health for midwifery and nursing students]. Jakarta: Salemba Medika, 2012.

19. Fadlyana E, Larasaty S. Pernikahan usia dini dan permasalahannya [Early marriage and its associated problems]. Sari Pediatri. 2009; 11(2): 136-140. 
20. Mufdlilah, Afriani R. Analisis dampak pernikahan dini pada remaja putri di Desa Sidoluhur Kecamatan Godean Yogyakarta [Impacts of early marriage in female adolescents in Sidoluhur Village, Godean Subdistrict, Yogyakarta]. In: Prosiding-Kontribusi Hasil Penelitian dan Pengabdian Masyarakat dalam Program Sustainable Development Goals (SDGs) (Proceeding-Contribution of studies and community works' results in Sustainable Development Goals (SDGs)). National Scientific Meeting on Studies and Community Works' Results. Muhammadiyah University. Semarang. 20 September 2016. 235-243.

21. Sarkar P. Determinants and effect of early marriage in Bangladesh, 2007. Research Journal of Applied Sciences. 2009; 4(5): 178-184 p.

22. Raj A. When the mother is a child: The impact of child marriage on the health and human rights of girls. Archives of Disease in Childhood. 2010. 95(11). 931-935 .

23. Gage AJ. Association of child marriage with suicidal thoughts and attempts among adolescent girls in Ethiopia. Journal of Adolescent Health. 2013; 52(5); 654-656.

24. Mawardi M. Problematika perkawinan di bawah umur (Problems of under-age marriage). Analisa. 2012; 19(2): 201-212.
25. UNICEF. Early marriage: A harmful traditional practice A statistical exploration. UNICEF. New York, USA. 2005

26. Aniq AF. Konflik peran gender pada tradisi merarik di Pulau Lombok (Gender roles conflict in merariq tradition in Lombok Island]. In: Conference Proceeding Annual International Conference on Islamic Studies. 2012; 2321-2339.

27. United Nations Human Rights. The convention on the Rights of the child. 1990. Available at: https://www.ohchr. org/EN/ProfessionalInterest/Pages/CRC.aspx

28. Djamilah, Kartikawati R. Dampak perkawinan anak di Indonesia [Impacts of child marriage in Indonesia]. Jurnal Studi Pemuda. 2014; 3: 1-16.

29. Ministry of Health of Indonesia. Pedoman Umum Program Indonesia Sehat dengan Pendekatan Keluarga [Guideline of Healthy Indonesia Program using FamilyBased Approach]. Ministry of Health of Indonesia. 2016.

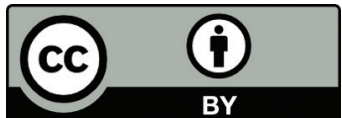

This work is licensed under a Creative Commons Attribution 